UDC 342.734

LBC 67.400.3;47

\title{
SOME QUESTIONS OF REALIZING BY FOREIGN CITIZENS OF THE CONSTITUTIONAL RIGHT TO LABOR WITHIN THE TERRITORY OF THE RUSSIAN FEDERATION
}

\author{
Sofya M. Shelegina \\ Department of Labor and Employment of the Sverdlovsk Region, Ekaterinburg, Russian Federation
}

Introduction: the article is devoted to studying the restrictions of the realization of the constitutional right of foreign citizens to labor within the territory of the Russian Federation and their grounds. On the basis of the analysis and generalization of the provisions of the current legislation of the Russian Federation concerning foreign citizens, the classification of foreign citizens depending on the nature of the legal relationship they enter into for the purpose of engagement in a labor activity is offered. The grounds and content of limits of realizing by foreign citizens the right to labor depending on age, nationality, the regime of legal stay within the territory of the Russian Federation are determined. The special attention is paid to the stages of the work permit process and the patent granting the right to engagement in a labor activity. In particular, the juridical facts that are the basis for the paperwork process are determined. The conclusion is drawn that in spite of the fact that in the Russian Federation the right to labor is proclaimed free, the legislator, concretizing its content in the current legislation, introduces the limits, the restrictions of its realization towards foreign citizens for the purpose of security of respect for the rights and freedoms of other persons, including the citizens of the Russian Federation, enshrined in the Constitution of the Russian Federation.

Key words: right of foreign citizens to labor, classification of foreign citizens, grounds for limits of realizing the right to work, stages of work permit process and patent, juridical facts.

УДК 342.734

ББК $67.400 .3 ; 47$

\section{НЕКОТОРЫЕ ВОПРОСЫ РЕАЛИЗАЦИИ ИНОСТРАННЫМИ ГРАЖДАНАМИ КОНСТИТУЦИОННОГО ПРАВА НА ТРУД НА ТЕРРИТОРИИ РОССИЙСКОЙ ФЕДЕРАЦИИ}

\author{
Софья Михайловна Шелегина \\ Департамент по труду и занятости населения Свердловской области, \\ г. Екатеринбург, Российская Федерация
}

\begin{abstract}
Введение: статья посвящена изучению ограничений реализации конституционного права иностранных граждан на труд на территории Российской Федерации (далее - РФ), их оснований. Исходя из анализа и обобщения положений действующего законодательства РФ в отношении иностранных граждан предложена классификация иностранных граждан в зависимости от характера правоотношений, в которые они в всупают с целью осуществления трудовой деятельности. Определены основания и содержание пределов реализации иностранными гражданами права на труд в зависимости от возраста, гражданства, режима законного нахождения на территории РФ. Особое внимание уделено этапам процесса оформления разрешения на работу и патента, дающих право на осуществление трудовой деятельности. Определены юридические факты, являющиеся основанием для начала процесса оформления документов. Сделан вывод о $\stackrel{\ominus}{\exists}$ том, что, несмотря на то что в РФ право на труд провозглашается свободным, законодатель, конкретизируя его содержание в текущем законодательстве, вводит пределы, ограничения его реализации в отношении
\end{abstract}




\section{ТЕОРИЯ И ПРАКТИКА ГОСУДАРСТВЕННО-ПРАВОВОГО РАЗВИТИЯ}

иностранных граждан с целью гарантированности соблюдения прав и свобод иных лиц, в том числе граждан РФ, закрепленных в Конституции РФ.

Ключевые слова: право иностранных граждан на труд, классификация иностранных граждан, основания пределов реализации права на труд, этапы процесса оформления разрешения на работу и патента, юридические факты.

\section{Введение}

Статья 2 Конституции Российской Федерации (далее - Конституция РФ) [3] провозглашает права и свободы человека и гражданина высшей ценностью, определяет необходимость их соблюдения и защиты в равной степени, что в системе действующего правового регулирования Российской Федерации (далее - РФ) является обязанностью государства [1, с. 195].

Конституция РФ, будучи актом наивысшей юридической силы, в ч. 2 ст. 17 [3] провозглашает основные права и свободы человека неотчуждаемыми, принадлежащими каждому от рождения. Кроме того, в соответствии с ч. 3 ст. 62 [3] на территории РФ лица, имеющие гражданство иного государства, или лица без гражданства наравне с гражданами России пользуются правами и несут соответствующие обязанности, кроме случаев, установленных федеральным законом или международным договором РФ. Не является исключением и право на труд, закрепленное в ч. 1 ст. 37 Конституции РФ [3]. Таким образом, вне зависимости от устойчивой правовой связи индивида с каким-либо другим государством, иных условий на территории РФ право на труд подлежит соблюдению и защите в случае его нарушения или умаления. Вместе с тем право на труд в отношении иностранных граждан и лиц без гражданства не безгранично, оно реализуется в установленных нормативными правовыми актами пределах. При этом условия реализации этого права неодинаковы. Учитывая данное обстоятельство, представляется необходимым рассмотреть возможные пределы реализации права иностранных граждан на труд на территории РФ.

\section{Пределы реализации права иностранных граждан на труд на территории РФ}

По смыслу ч. 1 ст. 37 Конституции РФ [3] право на труд рассматривается сквозь при- зму «свободы» [6, с. 31], которая в свою очередь определяет вариативность правового статуса иностранного гражданина. Так, например, лицо, имеющее гражданство иного государства, может быть участником трудовых правоотношений, заниматься индивидуальной трудовой деятельностью, не запрещенной законодательством РФ, либо заключать соглашения гражданско-правового характера. Подобное положение обеспечивает реализацию иностранным гражданином своих индивидуальных способностей, а также выбора профессии и рода деятельности, что предусмотрено ч. 1 ст. 37 Конституции РФ [3].

Право иностранных граждан на труд, как и любое иное конституционное право, конкретизируется в нормах действующего законодательства. Так, пределы реализации права на труд можно дифференцировать по различным основаниям, вытекающим из ч. 4 ст. 13 Федерального закона «О правовом положении иностранных граждан в Российской Федерации» (далее - Федеральный закон) [9].

Первое основание - возраст. Достижение 18 лет является обязательным условием для осуществления иностранным гражданином трудовой деятельности на территории РФ. Однако существуют исключения, например, в отношении иностранных граждан - спортсменов в возрасте до 18 лет, предусмотренные ст. 348.8 Трудового кодекса РФ [7].

Второе - гражданство иностранного гражданина - играет существенную роль в реализации данного права. Например, в отношении граждан Республики Беларусь, Республики Казахстан, Республики Армения, Кыргызской Республики ст. 97 договора о Евразийском экономическом союзе [2] предусмотрена возможность осуществления трудовой деятельности наравне с гражданами РФ. Иными словами, ограничения, предусмотренные федеральными законами и международными договорами, в соответствии со ст. 62 Конституции РФ [3] в некотором объеме не распространяются на указанную категорию лиц. 
Третье - режим законного нахождения на территории РФ - в соответствии с ч. 1 ст. 2 Федерального закона [9] предусматривает дифференциацию иностранных граждан по трем направлениям - иностранные граждане, временно пребывающие в $P \Phi$, а также временно и постоянно проживающие в РФ. В этом случае реализовать право на труд можно лишь при наличии необходимых документов - разрешения на работу (далее - РНР) или патента, обеспечивающих правомочность действий иностранного гражданина.

Однако в отличие от лиц, не являющихся гражданами РФ и временно или постоянно проживающих на ее территории, для иностранных граждан, временно пребывающих в РФ с целью осуществления трудовой деятельности, получение указанных документов обязательно. Об этом свидетельствуют положения ч. 4 ст. 13 Федерального закона [9]. Более того, в соответствии с п. 13 ч. 1 ст. 2 данного закона к «иностранным работникам» относятся лишь иностранные граждане, временно пребывающие в РФ, что подчеркивает особый статус данной категории лиц.

\section{Порядок получения разрешения на работу и патента}

Между тем РНР и патент не являются тождественными друг другу понятиями, что обусловлено различиями в порядке их получения. Рассмотрим их подробнее.

Вид документа, определяющий правомочность иностранного гражданина в отношении трудовой деятельности, зависит от заключения с РФ межгосударственного договора о безвизовом режиме. При наличии такового необходимо получение патента, в случае его отсутствия - РНР.

Процедура оформления РНР имеет более сложную структуру в отличие от патента. Первоначально работодателю необходимо подать заявку о потребности в привлечении и использовании иностранных работников в уполномоченный исполнительный орган государственной власти субъекта РФ (далее ИОГВ субъекта РФ). В этом случае юридическим фактом выступают самостоятельные действия работодателя. После чего представ- ленные данные анализируются на предмет наличия у работодателя правонарушений законодательства. Затем формируется потребность региона в иностранных работниках и выносится на обсуждение специально созданной межведомственной комиссии. Далее сведения о потребности направляются в Министерство труда и социальной защиты РФ (далее- Минтруд РФ) и проходят аналогичную процедуру обсуждения, после чего следует этап защиты ИОГВ субъекта РФ обозначенной потребности (квоты). Однако утверждение распределения квоты по субъектам происходит лишь на основании вступившего в силу акта Правительства РФ посредством принятия приказа Минтруда РФ.

По окончании данного этапа работодатель имеет возможность обратиться за выдачей разрешения на привлечение и использование иностранных работников, которое с юридической точки зрения свидетельствует о правомерности действий работодателя. Также лицо, привлекающее иностранных работников, имеет право одновременно подать документы для оформления РНР. Уполномоченным органом, осуществляющим выдачу обозначенных документов, является Управление по вопросам миграции ГУ МВД РФ [8] и его территориальные отделения (далее - Управление по вопросам миграции). В этом случае юридическим фактом также являются самостоятельные действия работодателя.

После поступления и принятия к рассмотрению всех необходимых документов Управление по вопросам миграции направляет межведомственный запрос о выдаче заключения о привлечении и использовании иностранных работников в ИОГВ субъекта РФ, который с учетом требований, предусмотренных приказом Минтруда РФ от 24 октября 2014 г. № 795н [4], оказывает данную государственную услугу и направляет указанное выше заключение в Управление по вопросам миграции. Далее работодателю выдается соответствующее разрешение, с учетом которого в последующем оформляется РНР на основании самостоятельно совершенных работодателем действий - юридических фактов.

В свою очередь оформление патента не требует какого-либо участия со стороны работодателя, поскольку данный вид докумен- 


\section{ТЕОРИЯ И ПРАКТИКА ГОСУДАРСТВЕННО-ПРАВОВОГО РАЗВИТИЯ}

та ориентирован на самостоятельное совершение иностранным гражданином или организацией, уполномоченной субъектом РФ, юридически значимых действий. Так, в соответствии с п. 2 ст. 13.3 Федерального закона [9] в течение 30 календарных дней со дня въезда в РФ иностранный гражданин представляет лично или через указанную ранее организацию в Управление по вопросам миграции все необходимые документы, закрепленные в ст. 13.3 Федерального закона [9]. Далее в соответствии с приказом Федеральной миграционной службы от 15 января 2015 г. № 5 [5] все заявленные сведения проходят процедуру проверки, принимаются на рассмотрение, по завершении которой иностранному гражданину выдается патент на основании п. 16 ч. 1 ст. 2 Федерального закона [9], дающий право на осуществление трудовой деятельности на территории субъекта РФ.

Таким образом, в процессе оформления разрешения на работу прослеживаются пять основных этапов: подача заявки о потребности в привлечении и использовании иностранных работников; определение потребности субъекта РФ в привлечении и использовании иностранных работников; защита и утверждение квоты; получение работодателем разрешения на привлечение и использование иностранных работников; получение работодателем разрешения на работу. В свою очередь процедура оформления патента ограничивается тремя этапами: представление иностранным гражданином или уполномоченной организацией необходимых для получения патента документов; рассмотрение заявления иностранного гражданина о выдаче патента; выдача иностранному гражданину патента.

\section{Выводы}

В заключение отметим, что, несмотря на то что в РФ право на труд провозглашается свободным, законодатель, конкретизируя его содержание в текущем законодательстве, вводит пределы, ограничения его реализации в отношении иностранных граждан. Основаниями таких ограничений выступают возраст, гражданство, а также режим законного нахождения на территории РФ. Это обстоятельство вызвано необходимостью гарантированности соблюдения прав и свобод иных лиц, в том числе граждан РФ, что вытекает из положения, закрепленного в ч. 3 ст. 17 Конституции РФ [3]. Данным фактом объясняется преобладание разрешительного порядка в процессе оформления РНР и патента, конкретизация процесса получения которых демонстрирует вариативность самих пределов, что проявляется даже в количестве этапов оформления разрешения на работу и патента.

\section{СПИСОК ЛИТЕРАТУРЫ}

1. Волчанская, А. Н. Защита прав человека: основные направления и пути развития / А. Н. Волчанская // Вестник Волгоградского государственного университета. Серия 5, Юриспруденция. 2012. - № 1 (16). - С. 195-200.

2. Договор о Евразийском экономическом союзе от 29 мая 2014 г. - Доступ из справ.-правовой системы «КонсультантПлюс».

3. Конституция Российской Федерации : (принята всенар. голосованием 12 дек. 1993 г.) // Собрание законодательства РФ. - 2014. - 4 авг. - № 31. - Ст. 4398.

4. Приказ Министерства труда и социальной защиты РФ «Об утверждении Порядка оформления и выдачи заключения о привлечении и об использовании иностранных работников» от 24 окт. 2014 г. № 795н // Российская газета. - 2015. - 30 янв. (№ 18).

5. Приказ Федеральной миграционной службы РФ «Об утверждении Административного регламента предоставления Федеральной миграционной службой государственной услуги по оформлению и выдаче иностранным гражданам патентов» от 15 янв. 2015 г. № 5. - Доступ из справ.-правовой системы «КонсультантПлюс».

6. Ростовщиков, И. В. Основные права личности в истории и современной России: законодательное признание и практика / И. В. Ростовщиков // Вестник Волгоградского государственного университета. Серия 5, Юриспруденция. - 2006. - № 8. - С. 25-32.

7. Трудовой кодекс Российской Федерации от 30 дек. 2001 г. № 197-Ф3 : (с изм. и доп.) // Российская газета. - 2001. - 31 дек. (№ 256).

8. Указ Президента РФ «О совершенствовании государственного управления в сфере контроля за оборотом наркотических средств, психотропных веществ и их прекурсоров и в сфере миграции» от 5 апр. 2016 г. № 156 // Собрание законодательства РФ. - 2016. - 11 апр. - № 15. - Ст. 2071.

9. Федеральный закон «О правовом положении иностранных граждан в Российской Федерации» от 25 июля 2002 г. № 115-Ф3 : (с изм. и доп.) // Российская газета. - 2002. - 31 июля (№ 140). 


\section{REFERENCES}

1. Volchanskaya A.N. Zashchita prav cheloveka: osnovnye napravleniya i puti razvitiya [The Protection of Human Rights: Main Directions and Ways of Development]. Vestnik Volgogradskogo gosudarstvennogo universiteta. Seriya 5, Yurisprudentsiya [Science Journal of Volgograd State University. Jurisprudence], 2012, no. 1 (16), pp. 195-200.

2. Dogovor o Evraziyskom ekonomicheskom soyuze ot 29 maya $2014 \mathrm{~g}$. [Agreement on the Eurasian Economic Union of May 29, 2014]. Access from KonsultantPlyus reference legal system.

3. Konstitutsiya Rossiyskoy Federatsii: (prinyata vsenar. golosovaniem 12 dek. 1993 g.) [The Constitution of the Russian Federation (Adopted by the Nation-Wide Voting on December 12, 1993)]. Sobranie zakonodatelstva $R F$ [Collected Legislation of the Russian Federation], 2014, August 4 (no. 31), art. 4398.

4. Prikaz Ministerstva truda i sotsialnoy zashchity RF «Ob utverzhdenii Poryadka oformleniya i vydachi zaklyucheniya o privlechenii $\mathrm{i}$ ob ispolzovanii inostrannykh rabotnikov» ot 24 okt. 2014 g. № 795n [The Order of the Ministry of Labour and Social Protection of the Russian Federation "On the Statement of the Order of Registration and Issue of the Conclusion about Attraction and Employment of Foreign Workers" of October 24, 2014 no. 795n]. Rossiyskaya gazeta, 2015, January 30 (no. 18).

5. Prikaz Federalnoy migratsionnoy sluzhby $R F$ «Ob utverzhdenii Administrativnogo reglamenta predostavleniya Federalnoy migratsionnoy sluzhboy gosudarstvennoy uslugi po oformleniyu $i$ vydache inostrannym grazhdanam patentov» ot 15 yanv. $2015 \mathrm{~g}$. № 5 [The Order of Federal Migration Service of the Russian Federation "On the Approval of Administrative
Regulations of Providing the State Service in Registration and Issue of Patents to Foreign Citizens by Federal Migration Service" of January 15, 2015 no. 5]. Access from KonsultantPlyus reference legal system.

6. Rostovshchikov I.V. Osnovnye prava lichnosti $\mathrm{v}$ istorii i sovremennoy Rossii: zakonodatelnoe priznanie i praktika [The Basic Rights of the Personality in the History and Modern Russia: Legislative Recognition and Practice]. Vestnik Volgogradskogo gosudarstvennogo universiteta. Seriya 5, Yurisprudentsiya [Science Journal of Volgograd State University. Jurisprudence], 2006, no. 8, pp. 25-32.

7. Trudovoy kodeks Rossiyskoy Federatsii ot 30 dek. 2001 g. № 197-FZ: (s izm. i dop.) [The Labour Code of the Russian Federation of December 30, 2001 no. 197-FL: (with amend. and add.)]. Rossiyskaya gazeta, 2001, December 31 (no. 256).

8. Ukaz Prezidenta $\mathrm{RF} \ll \mathrm{O}$ sovershenstvovanii gosudarstvennogo upravleniya $\mathrm{v}$ sfere kontrolya za oborotom narkoticheskikh sredstv, psikhotropnykh veshchestv $\mathrm{i}$ ikh prekursorov $\mathrm{i} v$ sfere migratsii» ot 5 apr. 2016 g. № 156 [The Decree of the President of the Russian Federation "On Improvement of Public Administration in the Sphere of Control of Trafficking in Narcotics, Psychotropic Substances and Their Precursors and in the Sphere of Migration" of April 5, 2016 no. 156]. Sobranie zakonodatelstva $R F$ [Collected Legislation of the Russian Federation], 2016, April 11 (no. 15), art. 2071.

9. Federalnyy zakon «O pravovom polozhenii inostrannykh grazhdan v Rossiyskoy Federatsii» ot 25 iyulya 2002 g. № 115-FZ: (s izm. i dop.) [The Federal Law of the Russian Federation "On the Legal Status of Foreign Citizens in the Russian Federation" of July 25, 2002 no. 115-FL: (with amend. and add.)]. Rossiyskaya gazeta, 2002, July 31, no. 140.

\section{Information about the Author}

Sofya M. Shelegina, Specialist of the Department of Human Resources and Migration Policy, Department of Labor and Employment of the Sverdlovsk Region, Furmanova St., 107, 620144 Ekaterinburg, Russian Federation, shelegina.sm@yandex.ru.

\section{Информация об авторе}

Софья Михайловна Шелегина, специалист Отдела трудовых ресурсов и миграционной политики, Департамент по труду и занятости населения Свердловской области, ул. Фурманова, 107, 620144 г. Екатеринбург, Российская Федерация, shelegina.sm@yandex.ru. 